\title{
The Enteric Nervous System and the Microenvironment of the Gut: The Translational Aspects of the Microbiome-Gut-Brain Axis
}

\author{
Fruzsina Mogor ${ }^{1} \mathbb{D}$, Tamás Kovács ${ }^{1}$, Zoltan Lohinai ${ }^{2}$ and David Dora ${ }^{1, *}$ (D) \\ 1 Department of Anatomy, Histology and Embryology, Semmelweis University, Tuzolto St. 58, \\ 1094 Budapest, Hungary; mogor.fruzsina@phd.semmelweis.hu (F.M.); \\ kovacs.tamas@med.semmelweis-univ.hu (T.K.) \\ 2 National Korányi Institute of Pulmonology, 1094 Budapest, Hungary; zoltan.lohinai@koranyi.hu \\ * Correspondence: dora.david@med.semmelweis-univ.hu; Tel.: +36-1-2156920
}

Citation: Mogor, F.; Kovács, T.; Lohinai, Z.; Dora, D. The Enteric Nervous System and the Microenvironment of the Gut: The Translational Aspects of the Microbiome-Gut-Brain Axis. Appl. Sci. 2021, 11, 12000. https:// doi.org/10.3390/app112412000

Academic Editor: Tatsuya Unno

Received: 28 October 2021

Accepted: 13 December 2021

Published: 16 December 2021

Publisher's Note: MDPI stays neutral with regard to jurisdictional claims in published maps and institutional affiliations.

Copyright: (c) 2021 by the authors. Licensee MDPI, Basel, Switzerland. This article is an open access article distributed under the terms and conditions of the Creative Commons Attribution (CC BY) license (https:// creativecommons.org/licenses/by/ $4.0 /)$.

\begin{abstract}
The proper functioning of the gastrointestinal tract is essential for digestion, absorption and the elimination of waste products. It protects us against pathogens, allergens and toxins, continuously monitoring and regulating the internal environment. The vast majority of these tasks are carried out by the nervous and immune systems of the gut in close cooperation by constantly adapting to internal and external stimuli, maintaining its homeostasis. In this review, we would like to summarize the most recent findings about the cytoarchitecture and functional microanatomy of the enteric nervous system and the immune microenvironment of the gut highlighting the essential role and inevitable molecular crosstalk between these two highly organized networks. Gut neuroimmunology is a rapidly evolving field and might help us to understand the etiology of inflammatory bowel disease and the systemic consequences of chronic intestinal inflammation. Finally, we also included a brief outlook to present the most recent research depicting the multifaceted role of the gut microbiome, its contribution to the gut-brain axis and human disease.
\end{abstract}

Keywords: enteric nervous system; muscularis macrophage; intraganglionic macrophage; barrier; gut neuroimmunology; microbiome; gut-brain axis

\section{The Immune Microenvironment of the Gut}

A properly functioning gastrointestinal tract digests food, absorbs nutrients and water and excretes the waste. To help digestion, it invites a microbiota of commensalists (symbionts), but inevitably faces hostile pathogens as well. The complex task of telling friend and foe apart is delegated to the innate and adaptive immune systems, the former is met with 'oral tolerance', while the latter is struggled by a controlled inflammation.

Antigens from the gut lumen make their way through the epithelium-via intestinal epithelial cells (IEC), macrophages (MP), or directly-into dendritic cells (DC; here considered as a subset of MP) of the lamina propria [1]. DCs then migrate to nearby lymph nodes to present those antigens to naive T cells (TC). TCs are familiar with 'friendly' antigens, which they encounter during their maturation in the thymus, thus they can respond selectively to luminal antigens. These 'friendly' antigens can induce a phenotype-shift to regulatory TCs $\left(\mathrm{T}_{\text {reg }}\right)$ with anti-inflammatory effects, whereas foreign antigens promote their differentiation to IL-17 producing helper TCs $\left(\mathrm{T}_{\mathrm{h} 17}\right)$, initiating a pro-inflammatory cascade with the recruitment of neutrophil granulocytes and natural killer cells (a group of innate lymphoid cells (ILCs)) [2,3]. The onset of IBD (Inflammatory Bowel Disease) is associated with the upset of this immunological equilibrium leading to uncontrolled inflammation [1].

The lumen of the gut is lined by intestinal epithelial cells (IECs) acting as a physical barrier for microbes: interconnected with tight junctions and coated with secreted mucus. Some IECs, goblet- and M cells (in the vicinity of Peyer's patches) help to deliver antigens to the subepithelial space via the transcytosis of microbes [4] (Figure 1 (1),(2)). In addition, 
IECs have a role in the pro-inflammatory pathway, providing chemical protection by producing antimicrobials, cytokines, and IgA [5] (Figure 1).

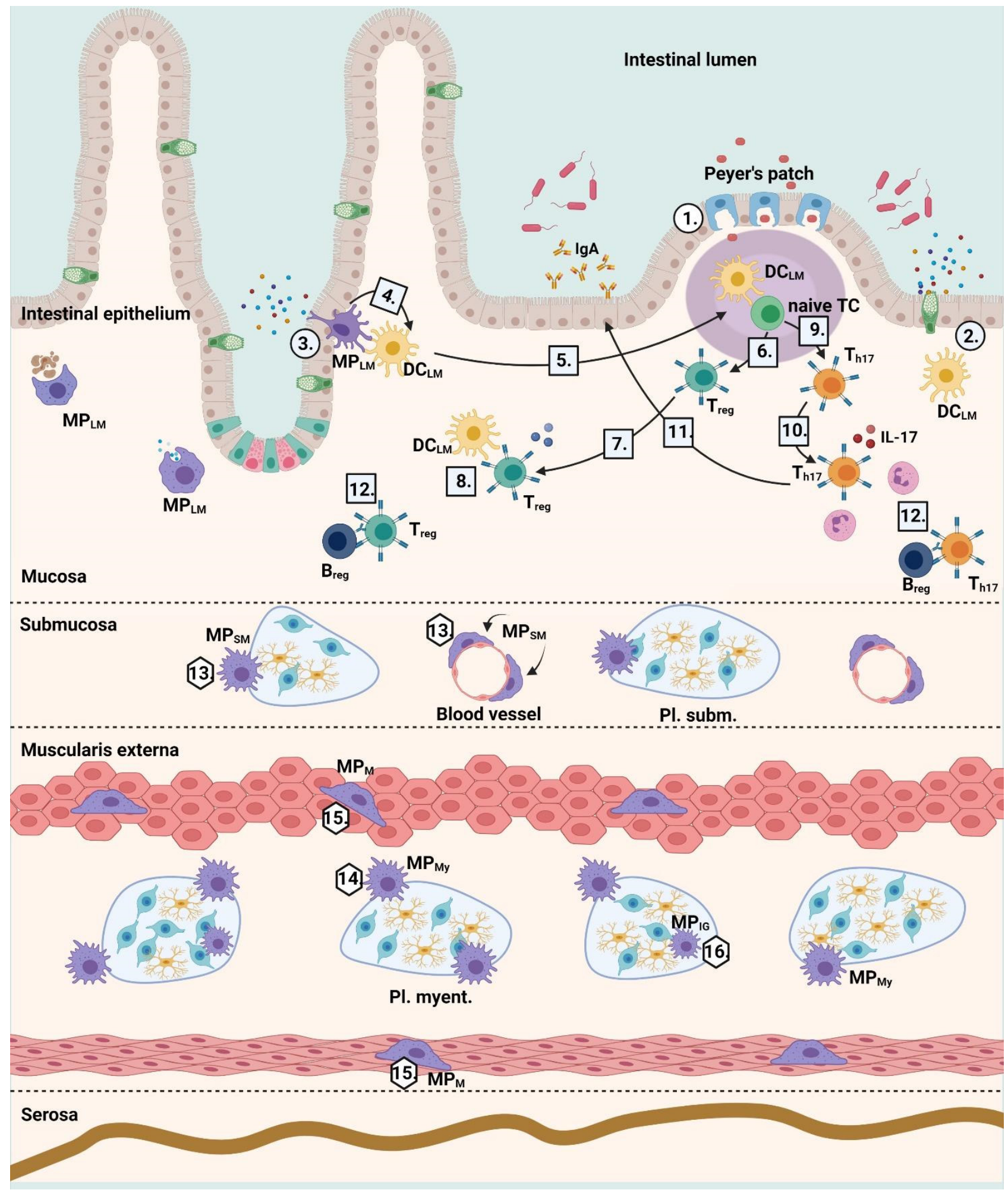

Figure 1. (1) M-cells in the vicinity of Peyer's patches sample the luminal microbes via transcytosis. (2) Goblet cells deliver antigens to the subepithelial space. (3) Lamina propria mucosae macrophages $\left(\mathrm{MP}_{\mathrm{LM}}-\mathrm{s}\right)$ grow transepithelial dendrites

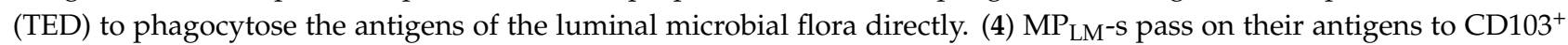
lamina propria mucosae dendritic cells $\left(\mathrm{DC}_{\mathrm{LM}}\right)$ through connexin-43-dependent gap junctions. (5) $\mathrm{DC}_{\mathrm{LM}^{-S}}$ migrate to the 
nearest lymph node. (6) Naive TCs differentiate to $\mathrm{T}_{\text {reg }}$ cells. (7) $\mathrm{T}_{\text {reg }}$ cells migrate to the mucosa where they produce anti-inflammatory interleukin 10 (IL-10). (8) $\mathrm{T}_{\text {reg cells induce the IL-10 production of MP }}$ LM cell. (9) Naive TCs differentiate into $T_{\text {h17 }}$ cells. (10) $T_{\text {h17 }}$ cells migrate to the mucosa and produce IL-17 (IL-17A, IL-17F) which recruit further neutrophil granulocytes and ILC3 cells. (11) $\mathrm{T}_{\mathrm{h} 17}$ cells also produce IL-22 which induces IECs to produce antimicrobial peptides

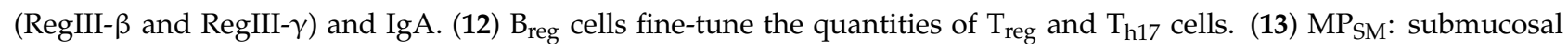
macrophage. (14) $\mathrm{MP}_{\mathrm{My}}$ : myenteric macrophage. (15) $\mathrm{MP}_{\mathrm{M}}$ : muscular macrophage. (16) $\mathrm{MP}_{\mathrm{IG}}$ : intraganglionic macrophage. Created with BioRender.

Subepithelially, in the lamina propria mucosae (LM), reside the mononuclear population

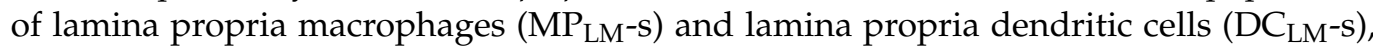
ordained to phagocytose antigens from the subepithelial space by growing transepithelial dendrites (TEDs) to sample the antigens of the luminal microbial flora [6]. TEDs do not compromise the integrity of the epithelial barrier, as they keep the adhesive structures of IECs intact (Figure 1, (3)). $\mathrm{MP}_{\mathrm{LM}^{-}}$-s pass on their antigens to $\mathrm{CD}_{103^{+}} \mathrm{DC}_{\mathrm{LM}^{-}}$-s through connexin-43-dependent gap junctions [7,8] (Figure 1, (4)). Once equipped with antigens, $\mathrm{CD}_{103}{ }^{+} \mathrm{DC}_{\mathrm{LM}^{-}} \mathrm{s}$ migrate to the nearest lymph node, where they activate naive TCs with TGF-B and retinoic acid [9] (Figure 1, (5)). By presenting their antigens to TCs, handing over the response to the adaptive immune system, $\mathrm{DC}_{\mathrm{LM}^{-}}$s delimit their role to a continuous 'surveillance' [10].

When friendly antigens (food or commensal microbiota) prime naive TCs, those differentiate to $\mathrm{CD} 4^{+} \mathrm{CD} 25^{+} \mathrm{Foxp}^{+} \mathrm{T}_{\text {reg }}$ cells [9] (Figure 1, (6)). $\mathrm{T}_{\text {reg }}$ cells migrate to the LM where they produce anti-inflammatory interleukin 10 (IL-10) and induce the IL-10 production of $\mathrm{MP}_{\mathrm{LM}}$ cells as well (Figure 1, (7),(8)). IL-10 leads to the expansion of $\mathrm{T}_{\text {reg }}$ cells, as a self-reinforcing effect, while $\mathrm{T}_{\text {reg }}$ cells also inhibit effector TCs [5]. The latter phenomenon is called 'oral tolerance', an active immunosuppressive process. The presence of commensal flora in the gut is essential in developing oral tolerance. This is underpinned by the fact that, in germ-free animals, the host becomes susceptible to food allergies [11]. Moreover, certain kinds of intestinal bacteria (e.g., Clostridia spp.) increase oral tolerance by priming $\mathrm{TC}$ s towards $\mathrm{T}_{\text {reg }}$ phenotype $[12,13]$.

Pathogen-activated naive TCs become $\mathrm{T}_{\mathrm{h} 17}$ cells [13]. $\mathrm{T}_{\mathrm{h} 17}$ cells produce the proinflammatory interleukin, IL-17 (IL-17A, IL-17F) which recruit further neutrophil granulocytes and ILC 3 cells $[14,15]$. ILC 3 cells are a group of ILCs that act as part of the innate immune response to extracellular bacteria and intestinal commensalists that produces IL-22 [3] (Figure 1, (9)). $\mathrm{T}_{\mathrm{h} 17}$ cells also produce IL-22, which induces IECs to produce antimicrobial peptides (RegIII- $\beta$ and RegIII- $\gamma$ ) and IgA [16] (Figure 1, (10),(11)) supporting the local immune defense of the intestine. In healthy organisms, immunoprotection and tolerance are in a regulated balance. Regulatory B-cells $\left(\mathrm{B}_{\mathrm{reg}}\right)$ can maintain this balance through IL-10 production and the fine-tuning of $\mathrm{T}_{\text {reg }}$ - and $\mathrm{T}_{\mathrm{h} 17}$ cellular differentiation [17,18] (Figure 1, (12)).

Chronic inflammation occurs in the upset of this equilibrium. In IBDs, such as Crohn's disease or ulcerative colitis, large amounts of imperfectly differentiated macrophages (with monocyte-like phenotypes) migrate into the mucosa and produce inflammatory cytokines, which may then feed a self-reinforcing process of increasingly severe inflammation with long-term effects [19].

In addition to mucosal inflammation, the muscularis externa layer is also involved in the pathophysiology of IBDs. As recently shown, long-term motility decline and increased transit time are caused by macrophages associated with the smooth muscle cells and ganglia of the deeper layers of the intestine [20,21]. These are the submucosal macrophages $\left(\mathrm{MP}_{\mathrm{SM}^{-}}{ }^{-\mathrm{S}}\right)$, located in the highly vascularized surroundings of the submucosal plexus, and the muscular macrophages $\left(\mathrm{MP}_{\mathrm{M}}-\mathrm{s}\right)$ of the muscularis externa layer, situated in the vicinity of the myenteric plexus or in the circular and longitudinal smooth muscle layers [19] (Figure 1, (13)). Until recently, we had a sparse knowledge about the role of these macrophages.

While the embryonic cells of $\mathrm{MP}_{\mathrm{LM}}$ macrophages are rapidly replaced after birth by monocytes of hematopoietic origin, migrating through the bloodstream, $\mathrm{MP}_{\mathrm{SM}}$ and $\mathrm{MP}_{\mathrm{M}}$ 
macrophages form a long-lived and self-sustaining population (resident macrophages) [22,23]. $\mathrm{MP}_{\mathrm{SM}}$ cells play an important role in supporting blood vessels, enteral neurons regulating intestinal secretion, as well as in tissue homeostasis [20] (Figure 1, (13)).

In their absence, a decrease of submucosal neural density and an increase of vascular permeability and disintegration occurs [24]. The primary task of $\mathrm{MP}_{\mathrm{M}}$ cells is to regulate gastrointestinal motility $[20,25,26]$, which we elaborate on in the following paragraphs.

\section{The Heterogeneity of Muscularis Macrophages}

$\mathrm{MP}_{\mathrm{M}}$ cells differ considerably from $\mathrm{MP}_{\mathrm{LM}}$ cells both in terms of molecular expression profile and morphology. They are described as $\mathrm{CD}_{4} 5^{+}$and $\mathrm{MHCII}^{+}$cells, with their high CX3CR1 expression separating them from $\mathrm{MP}_{\mathrm{LM}^{-}}{ }^{-\mathrm{S}}$ and their low $\mathrm{CD} 11 \mathrm{c}$ expression from $\mathrm{DC}_{\mathrm{LM}^{-}}$. In addition, they show high tissue protective Retnla, Mrc1, and CD163 gene expression [24]. Morphologically, two types of $\mathrm{MP}_{\mathrm{M}^{-}} \mathrm{S}$ are distinguished: bipolar with two long parallel protrusions, located between smooth muscle cells, or star-shaped ones, with microglia-like dendritic arborization, situated in close proximity to the myenteric plexus [27] (Figure 1, (14),(15)). Some $\mathrm{MP}_{\mathrm{M}}$ cells were shown to be in direct contact with the smooth muscle cells and interstitial cells of Cajal (ICCs). It has been shown, that $\mathrm{MP}_{\mathrm{M}}$-specific expression of TRPV4 receptor directly controls GI motility by interacting with smooth muscle cells $[27,28] . \mathrm{MP}_{\mathrm{M}}$-derived TRPV4 mediates the production of prostaglandin $\mathrm{E} 2$, which induces muscle contraction, a process independent of enteric neurons [28] (Figure 1, (15)). Furthermore, $\mathrm{MP}_{\mathrm{M}^{-}}$-s express BMP2 in the intestinal smooth muscle layer, which acts on enteric neurons. This is underlined by the fact that the blockade of BMP2 signaling or $\mathrm{MP}_{\mathrm{M}}$ depletion, causes dysmotility and prolonged intestinal transit time in mice [25].

Myenteric macrophages $\left(\mathrm{MP}_{\mathrm{My}}\right)$ are described as $\mathrm{MP}_{\mathrm{M}}$ cells closely related to the myenteric plexus and ENS ganglia [26] (Figure 1, (14)). Their maturation is largely influenced by factors of neural origin, as they express various neurotransmitter receptors, such as glycine-, nicotinic acetylcholine-, adrenergic-, and purine receptors [20]. Interestingly, these resident macrophages in mice already appear on the 8.5th embryonic day, before the formation of the myenteric plexus. Hence, $\mathrm{MP}_{\mathrm{My}}$ may play an important role in the development of the myenteric plexus, and the survival of enteric neurons, since depletion of a group of $\mathrm{MP}_{\mathrm{My}}$ causes a 50\% decrease in the number of enteric neurons with consequent intestinal dysmotility in mice [20]. Characteristics and phenotypic distinction of intestinal macrophages are elucidated in Table 1.

Enteric neural cells play a pivotal role in gastrointestinal motility, secretion andas discovered recently - in the regulation of the gut immune microenvironment. For comprehension of how the neuroimmunological crosstalk happens in the gut, first we summarize the latest knowledge about the diversity and function of this cell population. 
Table 1. The heterogeneity of intestinal macrophages according to surface markers, morphology, localization and function.

\begin{tabular}{|c|c|c|c|c|c|c|}
\hline Cell Type & $\mathrm{DC}_{\mathrm{LM}}$ & $\mathbf{M P}_{\mathrm{LM}}$ & $\mathrm{MP}_{\mathrm{SM}}$ & $\mathbf{M P}_{\mathbf{M}}$ & $\mathbf{M P}_{\mathbf{M y}}$ & $\mathrm{MP}_{\mathrm{IG}}$ \\
\hline Markers & $\begin{array}{c}\text { CD45 } \\
\text { MHCII } \\
\text { CD11b } \\
\text { F4/80 } \\
\text { CX3CR1 }^{+} /^{-} \\
\text {CD11c } \\
\text { CD103 }^{+} /- \\
\text {connexin-43 }\end{array}$ & $\begin{array}{c}\text { CD45 } \\
\text { MHCII } \\
\text { CD11b } \\
\text { F4/80 } \\
\text { CX3CR1 } 1^{\text {low }} /^{+} \\
\text {connexin-43 }^{+}\end{array}$ & $\begin{array}{c}\text { CD45 } \\
\text { MHCII } \\
\text { CD11b } \\
\text { F4/80 } \\
\text { CX3CR1 low } /^{+} \\
\text {CD11c low } /^{+}\end{array}$ & $\begin{array}{c}\text { CD45 } \\
\text { MHCII } \\
\text { CD11b } \\
\text { F4/80 } \\
\text { CX3CR1 } \\
\text { Retn1a } \\
\text { Mrc1 } \\
\text { CD163 } \\
\text { TRPV4 } \\
\text { BMP2 }\end{array}$ & $\begin{array}{l}\mathrm{MP}_{\mathrm{M}} \text { markers } \\
\text { glycine-, } \\
\text { nicotinic } \\
\text { acetylcholine--, } \\
\text { adrenergic-, } \\
\text { purine } \\
\text { receptors }\end{array}$ & $\begin{array}{c}\mathrm{MP}_{\mathrm{M}} \text { markers } \\
\text { Iba1, } \\
\text { CSF1R }\end{array}$ \\
\hline Morphology & amoeboid & amoeboid & amoeboid & $\begin{array}{c}\text { bipolar } \\
\text { star shaped }\end{array}$ & star shaped & star shaped \\
\hline Presence & $\begin{array}{c}\text { Lamina propria } \\
\text { mucosae }\end{array}$ & $\begin{array}{c}\text { Lamina propria } \\
\text { mucosae }\end{array}$ & Submucosa & Muscularis & $\begin{array}{l}\text { Myenteric } \\
\text { plexus }\end{array}$ & $\begin{array}{l}\text { Within the } \\
\text { ECM barrier of } \\
\text { myenteric } \\
\text { ganglions }\end{array}$ \\
\hline Role & $\begin{array}{l}\text { antigen } \\
\text { presentation, } \\
\text { TC activation }\end{array}$ & $\begin{array}{l}\text { phagocytosis of } \\
\text { antigens }\end{array}$ & $\begin{array}{l}\text { supporting of } \\
\text { blood vessels and } \\
\text { enteral neurons } \\
\text { regulating } \\
\text { intestinal secretion } \\
\text { tissue homeostasis }\end{array}$ & $\begin{array}{c}\text { regulation of } \\
\text { gastrointestinal } \\
\text { motility }\end{array}$ & $\begin{array}{l}\text { development of } \\
\text { the myenteric } \\
\text { plexus, } \\
\text { survival of } \\
\text { enteric neurons }\end{array}$ & $\begin{array}{l}\text { phagocytosis of } \\
\text { apoptotic } \\
\text { ganglionic cells }\end{array}$ \\
\hline
\end{tabular}

\section{Neurons and Neurochemistry of the Enteric Nervous System}

The oldest classification of enteric neurons was based on morphology [29]; this usually distinguished two morphological subpopulations: 'Dogiel type II' neurons with several long processes and 'Dogiel type I' neurons with numerous short processes. However, the restrictive dichotomy of the morphological data does not reflect the well-known chemical and functional diversity of enteric neurons. Electrophysiological classification of enteric neurons is also useful in defined circumstances. The first experiments to capture their electrical properties (which later provided the basis for classification) were recorded in the 1970s [30-32], where S (synaptic)- and AH (after-hyperpolarizing)-type neurons were identified. Despite the practicality of this classification, this kind of nomenclature has become obsolete now. Other functional subsets of enteric neurons can be inferred based on their axonal projection patterns, their synthesizing enzymes, calcium-binding proteins, cytoskeletal proteins and expression of primary transmitters [33,34]. Nowadays, the enteric neurons are mostly divided into four main classes: motoneurons, intrinsic primary afferent neurons (IPANs), interneurons and intestinofugal neurons. Motoneurons directly innervate the smooth muscle, blood vessels or glands, while intrinsic primary afferent neurons process signals from the intestinal microenvironment and transmit them to interneurons. The intestinofugal neurons are a special group of neurons that synapse directly with neurons of the prevertebral sympathetic ganglia. Altogether, 14 different subtypes had been described previously (summarized in Table 2), but in a recent study, a new intrinsic afferent neuron subtype was also identified [35]. The substances that act as neurotransmitters in the central nervous system are also found in the enteric nervous system, so that in addition to the classical neurotransmitters, several neuropeptides, and other neurotransmitters (adenosine triphosphate (ATP) and nitric oxide (NO)) also play an important role. To date, 20 different enteric neuron types and projections have been isolated, each using a different neurotransmitter combination (chemical coding). 
Table 2. Types of neurons in the enteric nervous system with their chemical coding and proportion.

\begin{tabular}{|c|c|c|c|}
\hline \# ID & Neuron Type & Incidence & Neurotransmitters \\
\hline \multicolumn{4}{|c|}{ Myenteric neurons } \\
\hline 6 & $\begin{array}{l}\text { Excitatory circular smooth muscle } \\
\text { motor neurons }\end{array}$ & $12 \%$ & $\begin{array}{c}\text { Acetylcholine/GABA (enkephalin, } \\
\text { tachykinins) }\end{array}$ \\
\hline 4 & $\begin{array}{l}\text { Excitatory longitudinal smooth } \\
\text { muscle motor neurons }\end{array}$ & $25 \%$ & $\begin{array}{l}\text { Acetylcholine/Calretinin } \\
\text { (tachykinins) }\end{array}$ \\
\hline 7 & $\begin{array}{l}\text { Inhibitory circular smooth muscle } \\
\text { motor neurons }\end{array}$ & $16 \%$ & $\begin{array}{l}\text { NOS/VIP } \\
(\mathrm{PACAP})\end{array}$ \\
\hline 5 & $\begin{array}{l}\text { Inhibitory longitudinal smooth } \\
\text { muscle motor neurons }\end{array}$ & $\sim 3 \%$ & NOS/VIP/GABA \\
\hline 1 & $\begin{array}{l}\text { Ascending interneurons } \\
\text { (local reflex circuit) }\end{array}$ & $5 \%$ & $\begin{array}{l}\text { Acetylcholine/Calretinin } \\
\text { (tachykinins) }\end{array}$ \\
\hline 8 & $\begin{array}{l}\text { Descending interneurons } \\
\text { (local reflex circuit) }\end{array}$ & $5 \%$ & Acetylcholine/NOS/VIP \\
\hline 9 & $\begin{array}{l}\text { Descending interneurons } \\
\text { (secretomotor reflex circuit) }\end{array}$ & $3 \%$ & Acetylcholine/Serotonin \\
\hline 10 & $\begin{array}{l}\text { Descending interneurons (migrating } \\
\text { myoelectric complex) }\end{array}$ & $4 \%$ & Acethylcholine/Somatostatin \\
\hline 2 & $\begin{array}{l}\text { Myenteric intrinsic primary afferent } \\
\text { neurons (IPAN) }\end{array}$ & $27 \%$ & $\begin{array}{l}\text { Acetylcholine/Calbindin } \\
\text { (tachykinins) }\end{array}$ \\
\hline 3 & Intestinofugal neurons & $1 \%$ & $\begin{array}{l}\text { Acetylcholine/VIP } \\
\text { (CCK, enkephalin) }\end{array}$ \\
\hline \multicolumn{4}{|c|}{ Submucosal neurons } \\
\hline 12 & $\begin{array}{c}\text { Non-cholinergic } \\
\text { secretomotor/vasodilator neurons }\end{array}$ & $45 \%$ & VIP/Galanin \\
\hline 13 & $\begin{array}{c}\text { Cholinergic secretomotor/vasodilator } \\
\text { neurons }\end{array}$ & $15 \%$ & Acetylcholine/Calretinin \\
\hline 14 & $\begin{array}{l}\text { Cholinergic secretomotor } \\
\text { non-vasodilator neurons }\end{array}$ & $29 \%$ & $\begin{array}{l}\text { Acetylcholine/NPY/CCK } \\
\text { (somatostatin, CGRP) }\end{array}$ \\
\hline 11 & $\begin{array}{c}\text { Submucosal intrinsic primary afferent } \\
\text { neurons }\end{array}$ & $11 \%$ & $\begin{array}{l}\text { Acetylcholine/Calbindin } \\
\text { (tachykinins) }\end{array}$ \\
\hline
\end{tabular}

The neurons of the mammalian enteric nervous system can be divided into three major groups based on their transmitter molecules: cholinergic, catecholaminergic and the socalled non-adrenergic cholinergic (NANC) groups of neurons. The main neurotransmitter of the latter is nitric oxide (NO). In nitrergic neurons, the enzyme nitric oxide synthase (NOS) is responsible for the production of NO- which is formed by the metabolism of arginine. There are three isoforms of NOS: neuronal NOS (nNOS), endothelial NOS (eNOS) and inducible NOS (iNOS). Because of its short-lived free radical nature, NO is fundamentally different from classical neurotransmitters and synaptic vesicles but is delivered to the target cell as a diffusible gas, where it has no receptor in the usual sense. In the postsynaptic cell, NO directly activates the guanylate cyclase that catalyzes the synthesis of cyclic guanosine monophosphate (cGMP), which leads to an increase in the cell's cGMP levels. The proportion of nitrergic neurons varies in the different stages of the intestinal tract. The nitrergic neurons are essentially inhibitory motoneurons of the longitudinal muscle layer and are therefore also responsible for the inhibition of descending peristalsis via interneurons, resulting in aboral relaxation of the intestinal tract.

In the enteric nervous system, neuropeptides constitute a major group of signaling molecules: neuropeptide Y (NPY) is found in both the peripheral and central nervous systems. NPY-ergic neurons are found in all layers of the intestine; some of them are extrin- 
sic, located mainly around blood vessels and synaptic in myenteric ganglia. The intrinsic NPY-ergic system includes motoneurons that inhibit the circular muscle layer, descending projections that modulate other neurons, and secretomotor neurons. It often co-exists as a co-transmitter with other neurotransmitters, such as $\mathrm{NO}$ or vasoactive intestinal peptide (VIP). Otherwise, the three NANC neurotransmitters have similar roles in the enteric nervous system: they can simultaneously affect motility, microcirculation, and secretion. Their inhibitory effects differ molecularly in that, while NO acts directly, NPY exerts its inhibitory effect on the intestinal wall smooth muscle via intrinsic cholinergic motor fibers. While VIP essentially executes the relaxation phase of the descending component of peristaltic movement, its homologue, substance $\mathrm{P}(\mathrm{SP})$, is responsible for the ascending, contractile component. Neurons expressing VIP are found in all four enteric neuron types. While NO modulates cGMP levels, VIP can activate the enzyme adenylate cyclase, thereby increasing cellular cAMP levels. In a subset of enteric neurons, VIP and NO act as co-transmitters in synergy to promote smooth muscle cell relaxation.

Glutamate acts in concert with other neurotransmitters. It is co-expressed with acetylcholine, SP, in rodent enteric neurons and its stimulatory effects on NOS have also been described. Glutamic acid produced in the intrinsic motor neurons of the myenteric plexus acts on two types of ionotropic receptors: the normally fast-response $\alpha$-amino-3-hydroxy-5methyl-4-isoxazolepropionic acid (AMPA) and the slowly activating $N$-methyl-D-aspartate (NMDA) receptors. Glutamate's special role is reflected in the fact that it was the first neurotransmitter to be detected in ascending intestinofugal projections that reach up to the brain. The role of this neurotransmitter in the functioning of the gut-brain axis has since become unquestioned.

Interestingly, one of the most common inhibitory neurotransmitters of the central nervous system, gamma-aminobutyrate (GABA), can depolarize postsynaptic cells in the alimentary canal. Smooth muscle contraction and relaxation can occur as a result of the GABAergic effect. GABAergic neurons appear to function as interneurons and can exert their effects on two types of receptors: excitatory $\mathrm{GABA}_{A}$ and inhibitory $\mathrm{GABA}_{B}$ receptors. Through the $\mathrm{GABA}_{\mathrm{A}}$ receptor, it exerts a motility stimulating effect on excitatory cholinergic and noradrenergic enteric projections, while it generates smooth muscle relaxation by activating nitrergic neurons. There is more evidence that GABA is also expressed in neurons of the submucosal plexus and is secreted paracrinally in mucosal enteroendocrine cells, thereby affecting absorption, secretion, and the intestinal immune system [36,37].

However, it is hard to build a universal classification of enteric neurons. Our conceptual understanding of enteric neurons and circuits comes from guinea pig studies: intrinsic afferent neurons, different types of ascending and descending interneurons, and muscle or mucosal motor neurons were identified in this species. Detailed knowledge on neuronal substances occurs from variety of gut segments from guinea pig, such as the small intestine [38,39], the colon [40] and the stomach [41]. Regional differences in the connectivity of the enteric nervous system (ENS) were observed in mice between the proximal versus distal colon, as well [42]. Our knowledge of human enteric neuron classes [43,44] and circuits [45] is much more limited due to the restricted access to human tissues. It is not possible to get a general picture-among other reasons-because of the differences between species. Furthermore, the 'one neuron-one function' concept is not supported anymore: intrinsic primary afferent neurons (IPANs) have been shown to be interneurons [46] and non-IPANs can also be regarded as sensory neurons $[47,48]$. Under experimental and pathological conditions the chemical coding of neurons may change [44]. The difficulty of combining different groupings, the difficulty of resolving discrepancies and technological advances have given rise to recent groupings based on scRNA sequencing data [49-52], which must be also integrated into the framework of ENS. The different cell types are shown in Figure 2 corresponding to their number. 


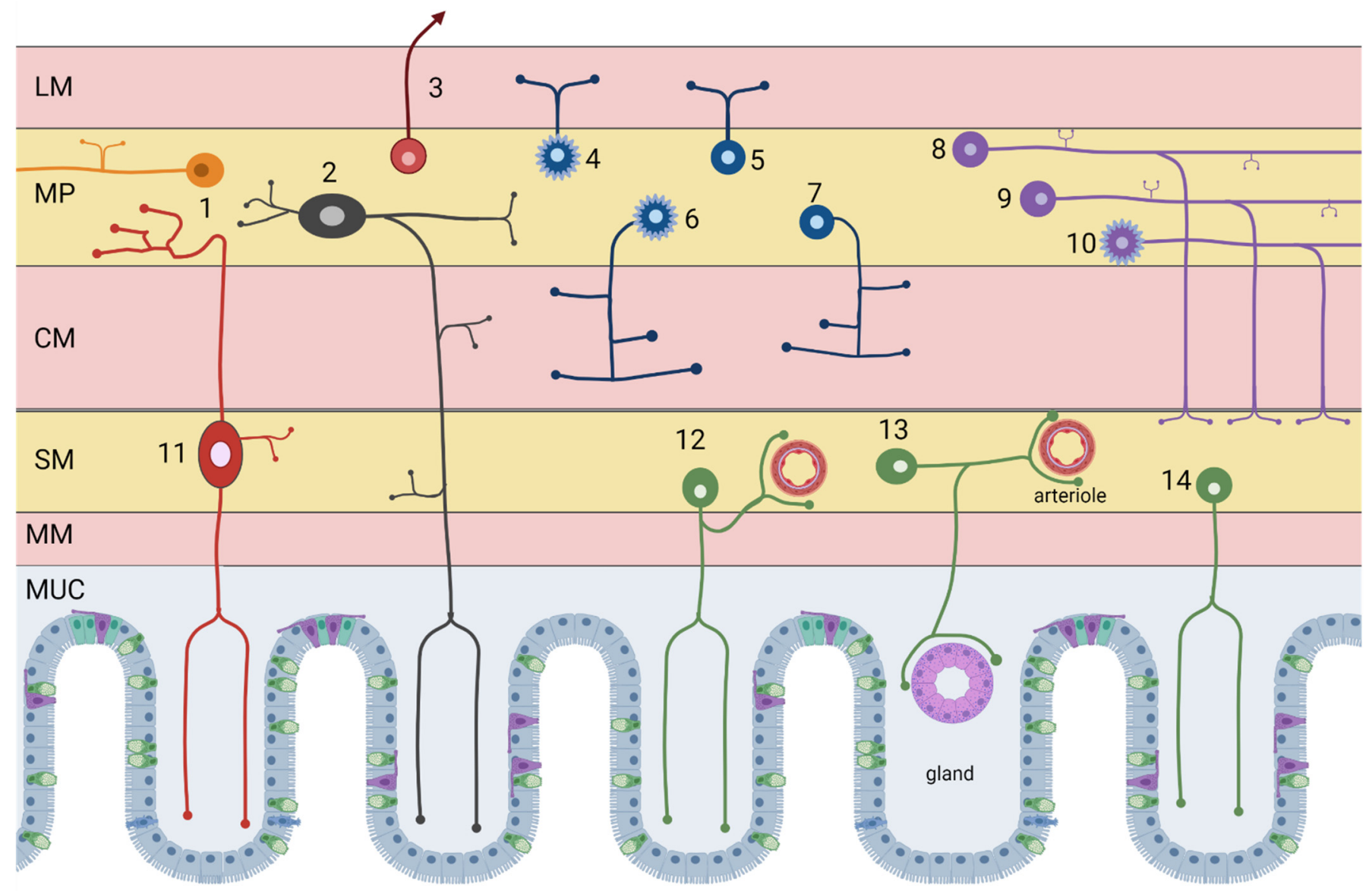

Figure 2. Neuron types in the ENS that have been defined by their functions, cell body morphologies, chemistries, key transmitters and projections to targets. LM longitudinal muscle, MP myenteric plexus, CM circular muscle, SM submucosal plexus, MM muscularis mucosae, MUC mucosa. The numbers neuron types corresponds to the numbers in ascending interneurons; 1. Ascending interneurons; 2: Myenteric intrinsic primary afferent neurons (IPANs); 3: Intestinofugal neurons; 4: Excitatory longitudinal muscle motor neurons; 5: Inhibitory longitudinal muscle motor neurons; 6: Excitatory circular muscle motor neurons; 7: Inhibitory circular muscle motor neurons; 8: Descending interneurons (local reflex); 9: Descending interneurons (secretomotor and motility reflex); 10: Descending interneurons (migrating myoelectric complex); 11: Submucosal IPANs; 12: Non-cholinergic secretomotor/vasodilator neurons; 13: Cholinergic secretomotor/vasodilator neurons; 14: Cholinergic secretomotor non-vasodilator neurons. Created with BioRender, modified from Lomax, 2000 [40].

\section{Intraganglionic Macrophages and the Myenteric Plexus Barrier}

Early histological studies identified macrophages closely juxtaposed to nerve fibers [53] and enteric neurons $[27,54]$, but according to recent findings, some $\mathrm{MP}_{\mathrm{M}^{-}}$s are entirely located within the extracellular matrix (ECM) barrier surrounding the myenteric plexus. These macrophages were identified as a unique cell population, called intraganglionic macrophages (MP IG) (Figure 1, (16)), characterized by the expression of multiple microglial markers and a distinct ultrastructure from their extraganglionic counterparts [21,55]. Although $\mathrm{MP}_{\mathrm{My}}$-s include cells whose cell bodies occur outside the ganglion, with their extensions reaching in the intraganglionic space (periganglionic macrophages), haemopoietic cells that are entirely located within the neuronal microenvironment of the ENS and express an immunological signature similar to central nervous system's (CNS), microglia (CD45, CD11b, Iba1, CSF1R) is a novel finding that further stratifies the already heterogenous population of $\mathrm{MP}_{\mathrm{M}^{-\mathrm{S}}}$ [55].

It is hypothesized that MHC-II+ macrophages in the vicinity of ganglion cells phagocytose apoptotic ganglion cells [56]. This feature is reminiscent of the so-called "scavenger" function of microglia. Based on gene expression studies, intestinal macrophages are closest 
to the microglia of the CNS [57]. These include genes related to the expression profile of the two cell populations: Hnmt, Mtus1, C3a1A, Dagla, Wrb, Fkbp9 or Gab1 [57]. The fractalkine receptor (CX3CR1) is one of the few molecular markers that are uniquely specific to intestinal macrophages and microglia, but not expressed by other tissue macrophages [8]. Signs of cellular degeneration, extensive cytoplasmic vacuolization and accumulation of swollen mitochondria but no membrane-blebbing or other morphological sign of apoptosis make $\mathrm{MP}_{\mathrm{IG}}$-s unique in terms of cellular morphology. Moreover, $\mathrm{MP}_{\mathrm{IG}}$-s show distinct ultrastructure from extraganglionic $\mathrm{MP}_{\mathrm{My}}$-s and have an active translational machinery and Golgi apparatus [21]. This might mean that $\mathrm{MP}_{\mathrm{My}}-\mathrm{s}$ and $\mathrm{MP}_{\mathrm{IG}}-\mathrm{s}$ have distinct roles in pathological conditions. A phenomena in the sciatic nerve underpins these observations, where transcriptionally unique perineurial and endoneurial macrophages are activated differentially in response to a crush injury [58].

Unlike the blood-brain-barrier (BBB) of the CNS we do not have much information about the blood-nerve barrier (BNB) protecting the ENS. While sensory dorsal root ganglia and autonomic parasympathetic and sympathetic ganglia include blood vessels, where monocytes can enter directly into the nervous tissue [59], there are no blood or lymphatic vessels inside enteric ganglia $[60,61]$. The extracellular matrix $(\mathrm{ECM})$ capsule covering the myenteric plexus has a structure similar to the BBB, made of agrin and collagen matrix proteins and covered by glial endfeet, surrounded by a collagen-rich periganglionic space. Due to its similar barrier function, it was described as the intestinal myenteric plexus barrier (MPB) [21]. In a mouse model of DSS-induced intestinal inflammation, the MPB disintegrates and the intravenously injected $4 \mathrm{kDa}$ FITC-dextran protein, which does not cross this barrier under physiological conditions, leaks inside the ganglia. The phenomenon is accompanied by an increase in $\mathrm{MP}_{\mathrm{IG}}$ cell number and MPB degradation does not occur in the absence of $\mathrm{M}_{\mathrm{M}^{-\mathrm{S}}}$ [21]. Neuronal or glial alteration and dysfunction in the ENS as a consequence of colitis were observed in multiple studies [62-64], with the direct causes underlying remaining unidentified. Disruption of the MPB might be responsible for long term dysmotility in IBD and other GI pathologies with acquired enteric neuronal dysfunction.

\section{The Neuroimmunological Crosstalk in the Gut: The Central Role of the ENS}

Alternating, peristaltic contractions of the smooth muscle layer of the intestinal tract (muscularis externa) are responsible for the gastrointestinal motility essential for nutrient transport and waste excretion, coordinated by the intrinsic system of the ENS. Although the neurons of the enteric ganglia receive extrinsic innervation from the sympathetic and parasympathetic fibers of the autonomic nervous system, they are able to function as a single autonomic unit, which is why the enteric nervous system is often referred to as the 'second brain' [65].

While there is extensive literature on the role of mucosal macrophages in gut immunity and secondary mucosal lymphatic tissue, little has been reported for a long time on macrophages of the muscularis externa. The two essential survival factors of the mononuclear cell line are FLT3 and CSF1. FLT3 is required for the survival of dendritic cells, whereas CSF1R is required for the survival of $\mathrm{MP}_{\mathrm{M}}-\mathrm{S}$, as evidenced by the disappearance of macrophages from the muscularis externa in CSF1R-KO mice and after intraperitoneal administration of a CSF1R-blocking antibody [25]. While $\mathrm{MP}_{\mathrm{M}}$ cells show an $80 \%$ depletion in response to the CSF1R-blocking antibody, the LpM population is not drastically affected by depletion treatments $[25,66]$.

BMP-like growth factors also play a role in the interaction of $\mathrm{MP}_{\mathrm{M}}-\mathrm{S}$ and the ENS. BMP2 and its receptor are well-known factors in the development and organization of embryonic smooth muscle and ENS [67,68]; BMP2 expression is specific for $\mathrm{MP}_{\mathrm{M}^{-\mathrm{s}}}$ in the intestinal smooth muscle layer, and blocking BMP signaling with dosomorphin, similar to the $\mathrm{MP}_{\mathrm{M}}$-depletion that is achieved with a CSF1R blockade, results in dysmotility and a prolonged intestinal transit time in mice [25]. In ex vivo colon cultures of mice treated with 
anti-CSF1R antibodies, the addition of BMP2 can reduce the motility impairment caused by $\mathrm{MP}_{\mathrm{M}}$-depletion [25].

BMP2 produced by $\mathrm{MP}_{\mathrm{M}}$-s in the smooth muscle layer acts on the BMPII receptor (BMPRII) of enteric neurons. Upon ligand binding of the receptor, a SMAD phosphorylation cascade is initiated [69], suggesting constitutive activation of $\mathrm{MP}_{\mathrm{M}}$-s on enteric neurons mediated by BMP2 [25]. This study suggests that the ENS produces CSF1 as part of a macrophage-neuron crosstalk in 'exchange' for ensuring the survival of the $\mathrm{MP}_{\mathrm{M}}$ population. However, subsequent studies have suggested that $\mathrm{MP}_{\mathrm{M}^{-\mathrm{S}}}$ colonize the gut even in the absence of ENS, and that CSF1 is predominantly produced by mucosal cells rather than ENS neurons [54].

In addition to the chemical crosstalk between intestinal macrophages and the ENS, the presence of a luminal microbial flora is required for proper motility of the intestinal tract, as supported by the development of severe intestinal dysmotility in homozygous mice reared in a germ-free environment [70] and expressing the TLR4 (toll-like receptor 4) gene [71]. In germ-free and antibiotic-treated TLR4-KO mutant mice, alterations in the neuronal phenotype of the ganglion, in particular a reduction in the number of nitrergic neurons, are thought to be responsible for reduced intestinal motility [71]. Antibiotic treatment of mice in vivo clearly reduces BMP2 expression levels, which is due to the depletion of the $\mathrm{MP}_{\mathrm{M}}$ population. As a consequence of BMP2 deficiency, the number of pSMAD1/5/8 positive enteric neurons in the intestinal tract is also reduced. A direct link between the commensal flora, macrophages and ENS is also suggested by the finding that adding LPS to primary enteric neuron cell culture (LPS, a systemic inflammatory mediator released from bacteria that dissociate during infection) increases neuronal CSF1 secretion in vitro [25]. Supplementation of antibiotic-treated mice with LPS may prevent downregulation of ENS CSF1 expression and a reduction in the number of $\mathrm{MP}_{\mathrm{M}^{-\mathrm{S}}}$ [25]. These results suggest that constant immunological stimulation of $\mathrm{MP}_{\mathrm{M}}{ }^{-\mathrm{s}}$ and enteric neurons by commensal flora is required to maintain healthy gut motility.

Both $\mathrm{MP}_{\mathrm{LM}^{-}}-\mathrm{s}$ and $\mathrm{MP}_{\mathrm{M}}$-s possess neurotransmitter receptors, such as $\beta 2$ adrenergic receptor ( $\beta 2 \mathrm{AR}$ ), however, $\mathrm{MP}_{\mathrm{M}}{ }^{-\mathrm{S}}$ show a much higher expression rate for the sympathetic neurotransmitter receptor. $\mathrm{MP}_{\mathrm{My}} \mathrm{s}$, a population of $\mathrm{MP}_{\mathrm{M}}$-s closely associated with the myenteric plexus of the ENS, show particularly high $\beta 2 \mathrm{AR}$ expression levels. The receptor ligand, the major source of noradrenaline, tyrosine hydroxylase $(\mathrm{TH})$, was shown to be positive extrinsic sympathetic neurons, whose central extensions come into proximity with enteric neurons and $\mathrm{MP}_{\mathrm{My}^{-}}$-s from outside the muscular layer, through the serosa. $\mathrm{TH}+$ neuronal extensions do not reach the lamina propria [26]. Catecholaminergic activation of the intestinal wall is predominantly mediated by postganglionic sympathetic fibers originating from the coeliac ganglion and the superior mesenteric ganglion, as confirmed by RiboTag cell labeling studies [26]. Noradrenergic sympathetic activation of the intestinal wall contributes primarily to the smooth muscle relaxation required for normal motility [72]. Oral administration of an enterocolitis-inducing bacterial strain (e.g., Salmonella Typhimurium) results in strong noradrenergic activation in the muscularis externa, with the source of this activation being the coeliac and the superior mesenteric ganglion. The released noradrenaline can indirectly regulate intestinal motility by acting on the $\beta 2 \mathrm{AR}$ of $\mathrm{MP}_{\mathrm{M}^{-\mathrm{S}}}$ [26]. Intestinal infection or $\beta 2 \mathrm{AR}$ activation by the adrenergic agonist salbutamol also induces changes in the gene expression profile of $\mathrm{MP}_{\mathrm{M}}$-s, triggering an alternative macrophage activation pathway, whereby cells release anti-inflammatory cytoprotective mediators and proinflammatory factors are downregulated [26]. Other studies have also shown that nociceptors innervated by the intestinal wall, extrinsic and intrinsic afferent fibers, can induce gene expression changes in Treg (regulatory T cells) cells upon microbial stimulation [73]. Based on the infection of an intestinal ex vivo experimental system with Clostridium ramosum bacteria, researchers hypothesize that certain microbes are able to directly activate intestinal nociceptive sensory fibers, triggering an early inflammatory and pain response in gastrointestinal infections [73]. 


\section{The Microbiome-Gut-Brain Axis}

The human body has more bacterial cells than eukaryotic. The skin, the respiratory tract, the urogenital tract and the intestine provide the largest and most diverse habitat for these microorganisms that live in commensal relationships with us, and which in turn influence the developmental and maturational processes of the alimentary tract together with its function. In many cases, the intestinal tract and its microbial flora perform digestion together and the molecular milieu that they produce provides a common input for higher immune, neuroendocrine and neurotransmitter capabilities. We call this unified structure the gut-brain axis, or, extendedly, the microbiome-gut-brain axis, which is based on the neuroimmunological interactions between the enteric nervous system and immune microenvironment of the gut. In a broader sense, the neuroendocrine and neuroimmune systems, such as the hypothalamic-pituitary-adrenal axis (HPA axis); the sympathetic and parasympathetic branches of the autonomic nervous system also contribute to this vast network. The first experiments suggesting the existence of a gut-brain axis connection were carried out by Pavlov, who found that certain sensory signals, such as the smell and sight of food, triggers the secretory function of the stomach and pancreas even before the food enters the oral cavity [74].

Interest in this research field was sparked by a 2004 study, which showed that mice kept in a germ-free environment showed an increased HPA response to stress [23]. The role of the microbiome in the gut-brain axis has been demonstrated in various experimental animals and a number of neuroactive substances produced by gut flora have been described. The role of gut flora composition in patients with various psychiatric and neurological conditions and the effects of probiotics began to be generally accepted [75]. However, it is still not fully understood whether changes in gut flora are a consequence, a cause, or both, of disease, through certain feedbacks mediated by the gut-brain axis [76,77].

Multiple bacterial species are identified as exogenic neurotransmitter producers. Lactobacillus and Bifidobacterium species secrete GABA; they can influence the social behavior of the host and thus contribute to alleviating symptoms of anxiety, stress and depression in humans by restoring the disrupted oxytocin balance [78].

The gut-brain axis not only plays an important role in providing local functions, but we are also starting to understand its wider implications. The late prenatal and early postnatal development of the human brain, mental development and changes in the microbiome coincide in time [79]. However, the correlation is not only apparent: in germ-free mice, not only brain structure abnormalities, but also abnormal mental development have been described [80], which may even be due to alterations in fetal microglia populations [81]. Environmental influences that disrupt the normal gut flora (e.g., maternal stress, prenatal infections, antibiotic use) increase the risk of neurodevelopmental and mental disorders [82]. Thus, as surprising and neglected as it may seem, gut flora is a critical player in the development of normal behavioral patterns [83]. Germ-free mice were shown to be more sensitive to visceral pain, but after fecal transplantation with wild-type mice, this sensitization was abolished. A similar situation was observed in response to antibiotic treatment or infection, a condition that was also restored by probiotic treatment [84]. Not only the neuroendocrine, immune and nervous systems are responsible for the stress response, but the composition of the commensal flora may also be affected. Some research suggests that a normal bacterial composition helps our resilience to stress $[83,85]$

The microbiome, which acts through the gut-brain axis, is becoming an increasingly important therapeutic target because of its presumptive link with mental and neurological disorders. Fecal microbiota transplantation (FMT), pre- and probiotic treatments have shown positive results in smaller cohorts of patients with depressive symptoms [86], and in mouse models of obsessive-compulsive disorder (OCD) [87]. In addition, abnormal alterations in gut flora have been reported in a number of psychiatric disorders and neurodevelopmental disorders, such as bipolar disorder, schizophrenia, autism (ASD) and attention deficit hyperactivity disorder (ADHD) [88]. 
According to recent studies, the microbiome influences the efficacy of cancer immunotherapy. Antigens of commensals can pass the intestinal barrier and result in T-cell priming, along with the stimulation of cytokine and interferon production, promoting an anti-tumor immune response on the basis of molecular mimicry [89]. Intestinal fungal species may interact with bacterial growth or can direct immune cell trafficking, especially inflammatory or tolerant immune responses that can emerge or evolve [90-92]. A beneficial effect of Bacteroidales in the immunostimulation associated with immune-checkpoint blockade was shown in recent studies $[93,94]$, whereas Li and colleagues showed that Bifidobacterium's oral administration had a similar effect as PD-L1-specific antibody therapy in experimental mouse models [95]. Another group described an association between the composition of the gut microbiome and immunotherapy efficacy on a sizable patient cohort of malignant melanoma [96]. Nonetheless, the prospect of the gut microbiome as a prognostic, and in the future, a potential therapeutic factor is immense and not negligible anymore. Despite the fact that FMT still has many limitations and risks, altering the human microbiome for therapeutic purposes cannot be rendered as an 'unscientific' or inceptive approach to fight diseases in the long term.

Several hypotheses have been proposed to describe the relationship between the aforementioned conditions and the microbiome, the most important of which are the 'old friend' hypothesis and the 'leaky gut theory'. The former, also known as the 'early immune challenge' hypothesis, is a key element in the tens of thousands of years of coevolution between our gut and elements of the commensal flora [97]. Substantial changes in our modern society (health, lifestyle, nutrition) have reduced our contact with our 'old friends' and thus altered immunological maturation processes. Indirectly, this leads to an increased incidence of allergic and autoimmune diseases and chronic inflammatory processes [98]. The leaky gut theory is associated with a reduction in the function of the barriers (BBB, epithelial barrier of the gut), as the altered microbiome causes the tight junctions to loosen and changes in intestinal permeability. Thus, the potential for bacterial translocation increases, circulating lipopolysaccharide and immunoglobulin levels arise, where cyclic macromolecules cross the BBB, generating neuroinflammatory processes [99]. Although each theory has a slightly different focus, they all recognize immunological dysfunction and the underlying changes in the gut-brain axis as a central background.

The gut microbiome plays an exceptional role in gut physiology. Being the largest contact area with the outer world lined by living cells it is continuously bombarded by immunological stimuli. We have already a plethora of circumstantial evidence of the fact that commensal microbiota effect the central nervous system and consequently, mental health. However, the identification of a direct link between the two networks supported by rigorous evidence has not been presented yet.

\section{Further Strategies on Microbiome Research}

The ENS and macrophages of the muscularis externa are perfect candidates to carry the role of these 'middlemen'. To find new directions and perspectives in the research field, there is an unmet need for novel and innovative research approaches. In addition to correlative studies between human disease and microbial communities, providing in vivo validation on the influence of microbiota on the immune and the nervous system is essential for the initiation of phase I clinical trials. Experiments involving FMT in germ-free murine models are resource-intensive and still have some limitations. Nonetheless, more and more of these studies succeed in proving not just the correlation but also the causation in vivo between microbiota and clinical parameters, including immunotherapy efficacy, systematic inflammation, IBD and neuropsychiatric conditions [94,100-103]. Microbial 'cocktails' may serve as future therapies for these burdening health conditions. Apart from preclinical studies, randomized clinical trials have already been started for a selected population of UC patients [104,105], where FMT was associated with a higher rate of combined clinical and endoscopic remission compared with placebo. Moreover, there was no increased risk of adverse events in FMT-treated patients compared to controls [106]. With the help of 
publicly available metagenome and transcriptomic databases, researchers can now find their target microbial taxa cost-effectively and prove their disease-modulator role on widely accessible animal models to create a basis for clinical trials in the future.

Author Contributions: Conceptualization, D.D., F.M., T.K. and Z.L.; resources, D.D. and Z.L.; writing—original draft preparation, D.D., F.M. and T.K.; writing—review and editing, D.D., F.M., T.K. and Z.L.; visualization, F.M. and T.K.; supervision, D.D.; project administration, D.D. and Z.L.; funding acquisition, D.D. All authors have read and agreed to the published version of the manuscript.

Funding: D. Dora acknowledge funding from the Hungarian National Research, Development and Innovation Office (OTKA \#124740) and from Semmelweis University's STIA-MEC 2020 grant.

Conflicts of Interest: The authors declare no conflict of interest. The funders had no role in the design of the study; in the collection, analyses, or interpretation of data; in the writing of the manuscript, or in the decision to publish the results.

\section{References}

1. Kmieć, Z.; Cyman, M.; Ślebioda, T.J. Cells of the innate and adaptive immunity and their interactions in inflammatory bowel disease. Adv. Med. Sci. 2017, 62,1-16. [CrossRef]

2. Denning, T.L.; Norris, B.A.; Medina-Contreras, O.; Manicassamy, S.; Geem, D.; Madan, R.; Karp, C.L.; Pulendran, B. Functional specializations of intestinal dendritic cell and macrophage subsets that control $\mathrm{TH}-17$ and $\mathrm{T}$ regulatory responses is dependent on the T:APC ratio, source of mouse strain and regional localization. J. Immunol. 2011, 18, 733-747. [CrossRef]

3. Vivier, E.; Artis, D.; Colonna, M.; Diefenbach, A.; Di Santo, J.P.; Eberl, G.; Koyasu, S.; Locksley, R.M.; McKenzie, A.N.J.; Mebius, R.E.; et al. Innate lymphoid cells: 10 years on. Cell 2018, 174, 1054-1066. [CrossRef]

4. Kurashima, Y.; Goto, Y.; Kiyono, H. Mucosal innate immune cells regulate both gut homeostasis and intestinal inflammation. Eur. J. Immunol. 2013, 43, 3108-3115. [CrossRef] [PubMed]

5. Sun, M.; He, C.; Cong, Y.; Liu, Z. Regulatory immune cells in regulation of intestinal inflammatory response to microbiota. Mucosal Immunol. 2015, 8, 969-978. [CrossRef]

6. Farache, J.; Koren, I.; Milo, I.; Gurevich, I.; Kim, K.W.; Zigmond, E.; Furtado, G.C.; Lira, S.A.; Shakhar, G. Luminal bacteria recruit CD103+ dendritic cells into the intestinal epithelium to sample bacterial antigens for presentation. Immunity 2013, 38, 581-595. [CrossRef]

7. Mazzini, E.; Massimiliano, L.; Penna, G.; Rescigno, M. Oral tolerance can be established via gap junction transfer of fed antigens from CX3CR1+ macrophages to CD103+ dendritic cells. Immunity 2014, 40, 248-261. [CrossRef]

8. Bain, C.C.; Schridde, A. Origin, Differentiation, and function of intestinal macrophages. Front. Immunol. 2018, 9, 1-15. [CrossRef] [PubMed]

9. Tordesillas, L.; Berin, M.C. Mechanisms of oral tolerance. Clin. Rev. Allergy Immunol. 2018, 55, 107-117. [CrossRef]

10. Lemos, M.P.; Fan, L.; Lo, D.; Laufer, T.M. CD8 $\alpha+$ and CD11b + dendritic cell-restricted MHC class II controls Th1 CD4 ${ }^{+}$T cell immunity. J. Immunol. 2003, 171, 5077-5084. [CrossRef] [PubMed]

11. Cahenzli, J.; Köller, Y.; Wyss, M.; Geuking, M.B.; McCoy, K.D. Intestinal microbial diversity during early-life colonization shapes long-term IgE levels. Cell Host Microbe 2013, 14, 559-570. [CrossRef]

12. Liu, Z.; Cao, A.T.; Cong, Y. Microbiota regulation of inflammatory bowel disease and colorectal cancer. Semin. Cancer Biol. 2013, 23, 543-552. [CrossRef] [PubMed]

13. Pandiyan, P.; Bhaskaran, N.; Zou, M.; Schneider, E.; Jayaraman, S.; Huehn, J. Microbiome Dependent regulation of tregs and Th17 cells in mucosa. Front. Immunol. 2019, 10,1-17. [CrossRef]

14. Spits, H.; Artis, D.; Colonna, M.; Diefenbach, A.; Di Santo, J.P.; Eberl, G.; Koyasu, S.; Locksley, R.M.; McKenzie, A.N.J.; Mebius, R.E.; et al. Innate lymphoid cells-a proposal for uniform nomenclature. Nat. Rev. Immunol. 2013, 13, 145-149. [CrossRef]

15. Weaver, C.T.; Elson, C.O.; Fouser, L.A.; Kolls, J.K. The Th17 pathway and inflammatory diseases of the intestines, lungs, and skin. Annu. Rev. Pathol. Mech. Dis. 2013, 8, 477-512. [CrossRef]

16. Zheng, Y.; Valdez, P.A.; Danilenko, D.M.; Hu, Y.; Sa, S.M.; Gong, Q.; Abbas, A.R.; Modrusan, Z.; Ghilardi, N.; De Sauvage, F.J.; et al. Interleukin-22 mediates early host defense against attaching and effacing bacterial pathogens. Nat. Med. 2008, 14, 282-289. [CrossRef]

17. Hong, M.; Liao, Y.; Liang, J.; Chen, X.; Li, S.; Liu, W.; Gao, C.; Zhong, Z.; Kong, D.; Deng, J.; et al. Immunomodulation of human CD19 + CD25 high regulatory B cells via Th17/Foxp3 regulatory T cells and Th1/Th2 cytokines. Hum. Immunol. 2019, 80, 863-870. [CrossRef]

18. Sattler, S.; Ling, G.S.; Xu, D.; Hussaarts, L.; Romaine, A.; Zhao, H.; Fossati-Jimack, L.; Malik, T.; Cook, H.T.; Botto, M.; et al. IL-10-producing regulatory B cells induced by IL-33 (BregIL-33) effectively attenuate mucosal inflammatory responses in the gut. J. Autoimmun. 2014, 50, 107-122. [CrossRef] [PubMed]

19. Na, Y.R.; Stakenborg, M.; Seok, S.H.; Matteoli, G. Macrophages in intestinal inflammation and resolution: A potential therapeutic target in IBD. Nat. Rev. Gastroenterol. Hepatol. 2019, 16, 531-543. [CrossRef] 
20. Viola, M.F.; Boeckxstaens, G. Intestinal resident macrophages: Multitaskers of the gut. Neurogastroenterol. Motil. 2020, $32,1-12$. [CrossRef] [PubMed]

21. Dora, D.; Ferenczi, S.; Stavely, R.; Toth, V.E.; Varga, Z.V.; Kovacs, T.; Bodi, I.; Hotta, R.; Kovacs, K.J.; Goldstein, A.M.; et al. Evidence of a myenteric plexus barrier and its macrophage-dependent degradation during murine colitis: Implications in enteric neuroinflammation. Cell. Mol. Gastroenterol. Hepatol. 2021, 12, 1617-1641. [CrossRef] [PubMed]

22. Bain, C.C.; Mowat, A.M. Macrophages in intestinal homeostasis and inflammation. Immunol. Rev. 2014, 260, 102-117. [CrossRef] [PubMed]

23. Shaw, T.N.; Houston, S.A.; Wemyss, K.; Bridgeman, H.M.; Barbera, T.A.; Zangerle-Murray, T.; Strangward, P.; Ridley, A.J.L.; Wang, P.; Tamoutounour, S.; et al. Tissue-resident macrophages in the intestine are long lived and defined by Tim-4 and CD4 expression. J. Exp. Med. 2018, 215, 1507-1518. [CrossRef]

24. De Schepper, S.; Verheijden, S.; Aguilera-Lizarraga, J.; Viola, M.F.; Boesmans, W.; Stakenborg, N.; Voytyuk, I.; Smidt, I.; Boeckx, B.; Dierckx de Casterlé, I.; et al. Self-maintaining gut macrophages are essential for intestinal homeostasis. Cell 2018, 175, 400-415.e13. [CrossRef] [PubMed]

25. Muller, P.A.; Koscsó, B.; Rajani, G.M.; Stevanovic, K.; Berres, M.L.; Hashimoto, D.; Mortha, A.; Leboeuf, M.; Li, X.M.; Mucida, D.; et al. Crosstalk between muscularis macrophages and enteric neurons regulates gastrointestinal motility. Cell 2014, 158, 300-313. [CrossRef]

26. Gabanyi, I.; Muller, P.A.; Feighery, L.; Oliveira, T.Y.; Costa-Pinto, F.A.; Mucida, D. Neuro-immune interactions drive tissue programming in intestinal macrophages. Cell 2016, 164, 378-391. [CrossRef] [PubMed]

27. Phillips, R.J.; Powley, T.L. Macrophages associated with the intrinsic and extrinsic autonomic innervation of the rat gastrointestinal tract. Auton. Neurosci. 2012, 169, 12-27. [CrossRef]

28. Luo, J.; Qian, A.; Oetjen, L.K.; Yu, W.; Yang, P.; Feng, J.; Xie, Z.; Liu, S.; Yin, S.; Dryn, D.; et al. TRPV4 channel signaling in macrophages promotes gastrointestinal motility via direct effects on smooth muscle cells. Immunity 2018, 49, 107-119.e4. [CrossRef] [PubMed]

29. Brehmer, A.; Schrödl, F; Neuhuber, W. Morphological classifications of enteric neurons-100 years after Dogiel. Anat. Embryol. 1999, 200, 125-135. [CrossRef]

30. Hirst, G.D.S.; Holman, M.E.; Spence, I. Two types of neurones in the Myenteric Plexus of duodenum in the guinea-pig. J. Physiol. 1974, 236, 303-326. [CrossRef]

31. Nishi, S.; North, R.A. Intracellular recording from the Myenteric Plexus of the guinea-pig ileum. J. Physiol. 1973, $231,471-491$. [CrossRef]

32. Wood, J.D.; Mayer, C.J. Intracellular study of electrical activity of Auerbach's Plexus in guinea-pig small intestine. Pflüg. Arch. Eur. J. Physiol. 1978, 374, 265-275. [CrossRef]

33. Mongardi Fantaguzzi, C.; Thacker, M.; Chiocchetti, R.; Furness, J.B. Identification of neuron types in the submucosal ganglia of the mouse ileum. Cell Tissue Res. 2009, 336, 179-189. [CrossRef]

34. Qu, Z.D.; Thacker, M.; Castelucci, P.; Bagyanszki, M.; Epstein, M.L.; Furness, J.B. Immunohistochemical analysis of neuron types in the mouse small intestine. Cell Tissue Res 2008, 334, 147-161. [CrossRef] [PubMed]

35. Nestor-Kalinoski, A.; Smith-Edwards, K.M.; Meerschaert, K.; Margiotta, J.F.; Rajwa, B.; Davis, B.M.; Howard, M.J. Unique neural circuit connectivity of mouse proximal, middle, and distal colon defines regional colonic motor patterns. Cell. Mol. Gastroenterol. Hepatol. 2021. ahead of print. [CrossRef]

36. Yoo, B.B.; Mazmanian, S.K. The enteric network: Interactions between the immune and nervous systems of the gut. Immunity 2017, 46, 910. [CrossRef]

37. Ma, X.; Sun, Q.; Sun, X.; Chen, D.; Wei, C.; Yu, X.; Liu, C.; Li, Y.; Li, J. Activation of GABAA receptors in colon epithelium exacerbates acute colitis. Front. Immunol. 2018, 9, 987. [CrossRef]

38. Brookes, S.J.H. Classes of enteric nerve cells in the guinea-pig small intestine. Anat. Rec. 2001, 262, 58-70. [CrossRef]

39. Costa, M.; Brookes, S.J.H.; Steele, P.A.; Gibbins, I.; Burcher, E.; Kandiah, C.J. Neurochemical classification of myenteric neurons in the guinea-pig ileum. Neuroscience 1996, 75, 949-967. [CrossRef]

40. Lomax, A.E.; Furness, J.B. Neurochemical classification of enteric neurons in the guinea-pig distal colon. Cell Tissue Res. 2000, 302, 59-72. [CrossRef] [PubMed]

41. Schemann, M.; Reiche, D.; Michel, K. Enteric pathways in the stomach. Anat. Rec. 2001, 262, 47-57. [CrossRef]

42. Li, Z.; Hao, M.M.; Van Den Haute, C.; Baekelandt, V.; Boesmans, W.; Berghe, P. Vanden regional complexity in enteric neuron wiring reflects diversity of motility patterns in the mouse large intestine. Elife 2019, 8, 1-27. [CrossRef]

43. Brehmer, A. Classification of human enteric neurons. Histochem. Cell Biol. 2021, 156, 95-108. [CrossRef] [PubMed]

44. Schemann, M.; Neunlist, M. The human enteric nervous system. Neurogastroenterol. Motil. 2004, 16 (Suppl. S1), 55-59. [CrossRef] [PubMed]

45. Graham, K.D.; López, S.H.; Sengupta, R.; Shenoy, A.; Schneider, S.; Wright, C.M.; Feldman, M.; Furth, E.; Valdivieso, F.; Lemke, A.; et al. Robust, 3-dimensional visualization of human colon enteric nervous system without tissue sectioning. Gastroenterology 2020, 158, 2221. [CrossRef] [PubMed]

46. Furness, J.B.; Kunze, W.A.A.; Bertrand, P.P.; Clerc, N.; Bornstein, J.C. Intrinsic primary afferent neurons of the intestine. Prog. Neurobiol. 1998, 54, 1-18. [CrossRef] 
47. Spencer, N.J.; Hu, H. Enteric nervous system: Sensory transduction, neural circuits and gastrointestinal motility. Nat. Rev. Gastroenterol. Hepatol. 2020, 17, 338-351. [CrossRef]

48. Spencer, N.J.; Smith, T.K. Mechanosensory S-neurons rather than AH-neurons appear to generate a rhythmic motor pattern in guinea-pig distal colon. J. Physiol. 2004, 558, 577-596. [CrossRef]

49. May-Zhang, A.A.; Tycksen, E.; Southard-Smith, A.N.; Deal, K.K.; Benthal, J.T.; Buehler, D.P.; Adam, M.; Simmons, A.J.; Monaghan, J.R.; Matlock, B.K.; et al. Combinatorial transcriptional profiling of mouse and human enteric neurons identifies shared and disparate subtypes in situ. Gastroenterology 2021, 160, 755-770.e26. [CrossRef]

50. Morarach, K.; Mikhailova, A.; Knoflach, V.; Memic, F.; Kumar, R.; Li, W.; Ernfors, P.; Marklund, U. Diversification of molecularly defined myenteric neuron classes revealed by single-cell RNA eequencing. Nat. Neurosci. 2021, 24, 34-46. [CrossRef]

51. Wright, C.M.; Schneider, S.; Smith-Edwards, K.M.; Mafra, F.; Leembruggen, A.J.L.; Gonzalez, M.V.; Kothakapa, D.R.; Anderson, J.B.; Maguire, B.A.; Gao, T.; et al. ScRNA-seq reveals new enteric nervous system roles for GDNF, NRTN, and TBX3. Cell. Mol. Gastroenterol. Hepatol. 2021, 11, 1548-1592.e1. [CrossRef]

52. Zeisel, A.; Hochgerner, H.; Lönnerberg, P.; Johnsson, A.; Memic, F.; van der Zwan, J.; Häring, M.; Braun, E.; Borm, L.E.; La Manno, G.; et al. Molecular architecture of the mouse nervous system. Cell 2018, 174, 999-1014.e22. [CrossRef]

53. Mikkelsen, H. Macrophages in the external muscle layers of mammalian intestines. Histol. Histopathol. 1995, 10, 719-736. [PubMed]

54. Avetisyan, M.; Rood, J.E.; Lopez, S.H.; Sengupta, R.; Wright-Jin, E.; Dougherty, J.D.; Behrens, E.M.; Heuckeroth, R.O. Muscularis macrophage development in the absence of an enteric nervous system. Proc. Natl. Acad. Sci. USA 2018, 115, 4696-4701. [CrossRef]

55. Dora, D.; Arciero, E.; Hotta, R.; Barad, C.; Bhave, S.; Kovacs, T.; Balic, A.; Goldstein, A.M.; Nagy, N. Intraganglionic macrophages: A new population of cells in the enteric ganglia. J. Anat. 2018, 233, 401-410. [CrossRef] [PubMed]

56. Kulkarni, S.; Micci, M.A.; Leser, J.; Shin, C.; Tang, S.C.; Fu, Y.Y.; Liu, L.; Li, Q.; Saha, M.; Li, C.; et al. Adult enteric nervous system in health is maintained by a dynamic balance between neuronal apoptosis and neurogenesis. Proc. Natl. Acad. Sci. USA 2017, 114, E3709-E3718. [CrossRef]

57. Gautier, E.L.; Shay, T.; Miller, J.; Greter, M.; Jakubzick, C.; Ivanov, S.; Helft, J.; Chow, A.; Elpek, K.G.; Gordonov, S.; et al. Geneexpression profiles and transcriptional regulatory pathways that underlie the identity and diversity of mouse tissue macrophages. Nat. Immunol. 2012, 13, 1118-1128. [CrossRef] [PubMed]

58. Ydens, E.; Amann, L.; Asselbergh, B.; Scott, C.L.; Martens, L.; Sichien, D.; Mossad, O.; Blank, T.; De Prijck, S.; Low, D.; et al. Profiling peripheral nerve macrophages reveals two macrophage subsets with distinct localization, transcriptome and response to injury. Nat. Neurosci. 2020, 23, 676-689. [CrossRef]

59. Monaco, S.; Gehrmann, J.; Raivich, G.; Kreutzberg, G.W. MHC-positive, ramified macrophages in the normal and injured rat peripheral nervous system. J. Neurocytol. 1992, 21, 623-634. [CrossRef]

60. Gershon, M.D.; Bursztajn, S. Properties of the enteric nervous system: Limitation of access of intravascular macromolecules to the myenteric plexus and muscularis externa. J. Comp. Neurol. 1978, 180, 467-487. [CrossRef]

61. Kiernan, J.A. Vascular permeability in the peripheral autonomic and somatic nervous systems: Controversial aspects and comparisons with the blood-brain barrier. Microsc. Res. Tech. 1996, 35, 122-136. [CrossRef]

62. Pochard, C.; Coquenlorge, S.; Freyssinet, M.; Naveilhan, P.; Bourreille, A.; Neunlist, M.; Rolli-Derkinderen, M. The multiple faces of inflammatory enteric glial cells: Is Crohn's Disease a gliopathy? Rev. Enteric Nerv. Syst. Heal. Dis. Am. J. Physiol. Gastrointest. Liver Physiol. 2018, 315, 1-11. [CrossRef] [PubMed]

63. Spear, E.T.; Mawe, G.M. Enteric neuroplasticity and dysmotility in inflammatory disease: Key players and possible therapeutic targets. Am. J. Physiol. Gastrointest. Liver Physiol. 2019, 317, G853-G861. [CrossRef] [PubMed]

64. Stavely, R.; Abalo, R.; Nurgali, K. Targeting enteric neurons and plexitis for the management of inflammatory Bowel disease. Curr. Drug Targets 2020, 21, 1428-1439. [CrossRef]

65. Nagy, N.; Goldstein, A.M. Enteric nervous system development: A crest cell's journey from neural tube to colon. Semin. Cell Dev. Biol. 2017, 66, 94-106. [CrossRef] [PubMed]

66. Bogunovic, M.; Ginhoux, F.; Helft, J.; Shang, L.; Hashimoto, D.; Greter, M.; Liu, K.; Jakubzick, C.; Ingersoll, M.A.; Leboeuf, M.; et al. Origin of the lamina propria dendritic cell network. Immunity 2009, 31, 513-525. [CrossRef]

67. Chalazonitis, A.; Kessler, J.A. Pleiotropic Effects of the bone morphogenetic proteins on development of the enteric nervous system. Dev. Neurobiol. 2012, 72, 843-856. [CrossRef]

68. Goldstein, A.M.; Brewer, K.C.; Doyle, A.M.; Nagy, N.; Roberts, D.J. BMP Signaling is necessary for neural crest cell migration and ganglion formation in the enteric nervous system. Mech. Dev. 2005, 122, 821-833. [CrossRef]

69. Derynck, R.; Zhang, Y.E. Smad-dependent and smad-independent pathways in TGF- $\beta$ family signalling. Nature 2003, 425, 577-584. [CrossRef]

70. Abrams, G.D.; Bishop, J.E. Effect of the normal microbial flora on gastrointestinal motility. Proc. Soc. Exp. Biol. Med. 1967, 126, 301-304. [CrossRef]

71. Anitha, M.; Vijay-Kumar, M.; Sitaraman, S.V.; Gewirtz, A.T.; Srinivasan, S. Gut microbial products regulate murine gastrointestinal motility via toll-like receptor 4 signaling. Gastroenterology 2012, 143, 1006-1016.e4. [CrossRef]

72. Pullinger, G.D.; van Diemen, P.M.; Carnell, S.C.; Davies, H.; Lyte, M.; Stevens, M.P. 6-Hydroxydopamine-mediated release of norepinephrine increases faecal excretion of salmonella enterica serovar typhimurium in pigs. Vet. Res. 2010, 41, 68. [CrossRef] [PubMed] 
73. Yissachar, N.; Zhou, Y.; Ung, L.; Lai, N.Y.; Mohan, J.F.; Ehrlicher, A.; Weitz, D.A.; Kasper, D.L.; Chiu, I.M.; Mathis, D.; et al. An intestinal organ culture system uncovers a role for the nervous system in microbe-immune crosstalk. Cell 2017, 168, 1135-1148.e12. [CrossRef] [PubMed]

74. Pavlov, I.P. Conditioned Reflexes: An Investigation of the Physiological Activity of the Cerebral Cortex; Dover Publications: Mineola, NY, USA, 1904

75. Wang, H.; Lee, I.S.; Braun, C.; Enck, P. Effect of probiotics on central nervous system functions in animals and humans: A systematic review. J. Neurogastroenterol. Motil. 2016, 22, 589-605. [CrossRef] [PubMed]

76. Schneiderhan, J.; Master-Hunter, T.; Locke, A. Targeting gut flora to treat and prevent disease. J. Fam. Pract. 2016, 65, 34-38.

77. Wang, Y.; Kasper, L.H. The role of microbiome in central nervous system disorders. Brain. Behav. Immun. 2014, 38, 1-12. [CrossRef]

78. Johnson, K.V.-A.; Foster, K.R. Why does the microbiome affect behaviour? Nat. Rev. Microbiol. 2018, 16, 647-655. [CrossRef]

79. Desbonnet, L.; Clarke, G.; Shanahan, F.; Dinan, T.G.; Cryan, J.F. Microbiota is essential for social development in the mouse. Mol. Psychiatry 2014, 19, 146-148. [CrossRef]

80. Heijtz, R.D.; Wang, S.; Anuar, F.; Qian, Y.; Björkholm, B.; Samuelsson, A.; Hibberd, M.L.; Forssberg, H.; Pettersson, S. Normal gut microbiota modulates brain development and behavior. Proc. Natl. Acad. Sci. USA 2011, 108, 3047-3052. [CrossRef]

81. Thion, M.S.; Low, D.; Silvin, A.; Chen, J.; Grisel, P.; Schulte-Schrepping, J.; Blecher, R.; Ulas, T.; Squarzoni, P.; Hoeffel, G.; et al. Microbiome influences prenatal and adult microglia in a sex-specific manner. Cell 2018, 172, 500-516.e16. [CrossRef]

82. Slykerman, R.F.; Thompson, J.; Waldie, K.E.; Murphy, R.; Wall, C.; Mitchell, E.A. Antibiotics in the first year of life and subsequent neurocognitive outcomes. Acta Paediatr. 2017, 106, 87-94. [CrossRef] [PubMed]

83. Vuong, H.E.; Yano, J.M.; Fung, T.C.; Hsiao, E.Y. The microbiome and host behavior. Annu. Rev. Neurosci. 2017, 40, 21-49. [CrossRef] [PubMed]

84. Luczynski, P.; Tramullas, M.; Viola, M.; Shanahan, F.; Clarke, G.; O’Mahony, S.; Dinan, T.G.; Cryan, J.F. Microbiota regulates visceral pain in the mouse. Elife 2017, 6, e25887. [CrossRef]

85. Moloney, R.D.; Desbonnet, L.; Clarke, G.; Dinan, T.G.; Cryan, J.F. The microbiome: Stress, health and disease. Mamm. Genome 2014, 25, 49-74. [CrossRef]

86. Wallace, C.J.K.; Milev, R. The effects of probiotics on depressive symptoms in humans: A systematic review. Ann. Gen. Psychiatry 2017, 16, 14. [CrossRef]

87. Kantak, P.A.; Bobrow, D.N.; Nyby, J.G. Obsessive-compulsive-like behaviors in house mice are attenuated by a probiotic (Lactobacillus Rhamnosus GG). Behav. Pharmacol. 2014, 25, 71-79. [CrossRef]

88. Dickerson, F.; Severance, E.; Yolken, R. The microbiome, immunity, and Schizophrenia and Bipolar Disorder. Brain. Behav. Immun. 2017, 62, 46-52. [CrossRef]

89. Zitvogel, L.; Ayyoub, M.; Routy, B.; Kroemer, G. Microbiome and anticancer immunosurveillance. Cell 2016, 165, $276-287$. [CrossRef]

90. Nguyen, L.D.N.; Viscogliosi, E.; Delhaes, L. The lung mycobiome: An emerging field of the human respiratory microbiome. Front. Microbiol. 2015, 6, 89. [CrossRef] [PubMed]

91. Enaud, R.; Prevel, R.; Ciarlo, E.; Beaufils, F.; Wieërs, G.; Guery, B.; Delhaes, L. The gut-lung axis in health and respiratory diseases: A place for inter-organ and inter-kingdom crosstalks. Front. Cell. Infect. Microbiol. 2020, 10, 9. [CrossRef]

92. Barcik, W.; Boutin, R.C.T.; Sokolowska, M.; Finlay, B.B. The role of lung and gut microbiota in the pathology of asthma. Immunity 2020, 52, 241. [CrossRef]

93. Yi, M.; Yu, S.; Qin, S.; Liu, Q.; Xu, H.; Zhao, W.; Chu, Q.; Wu, K. Gut microbiome modulates efficacy of immune checkpoint inhibitors. J. Hematol. Oncol. 2018, 11, 47. [CrossRef]

94. Gong, J.; Chehrazi-Raffle, A.; Placencio-Hickok, V.; Guan, M.; Hendifar, A.; Salgia, R. The gut microbiome and response to immune checkpoint inhibitors: Preclinical and clinical strategies. Clin. Transl. Med. 2019, 8, 9. [CrossRef] [PubMed]

95. Li, Q.; Li, Y.; Wang, Y.; Xu, L.; Guo, Y.; Wang, Y.; Wang, L.; Guo, C. Oral administration of bifidobacterium breve promotes antitumor efficacy via dendritic cells-derived Interleukin 12. Oncoimmunology 2021, 10, 1868122. [CrossRef]

96. Matson, V.; Fessler, J.; Bao, R.; Chongsuwat, T.; Zha, Y.; Alegre, M.-L.; Luke, J.J.; Gajewski, T.F. The commensal microbiome is associated with Anti-PD-1 efficacy in metastatic melanoma patients. Science 2018, 359, 104-108. [CrossRef]

97. Rook, G.A. Regulation of the immune system by biodiversity from the natural environment: An ecosystem service essential to health. Proc. Natl. Acad. Sci. USA 2013, 110, 18360-18367. [CrossRef] [PubMed]

98. Kramer, A.; Bekeschus, S.; Bröker, B.M.; Schleibinger, H.; Razavi, B.; Assadian, O. Maintaining health by balancing microbial exposure and prevention of infection: The hygiene hypothesis versus the hypothesis of early immune challenge. J. Hosp. Infect. 2013, 83 (Suppl. S1), S29-S34. [CrossRef]

99. Slyepchenko, A.; Maes, M.; Jacka, F.N.; Köhler, C.A.; Barichello, T.; McIntyre, R.S.; Berk, M.; Grande, I.; Foster, J.A.; Vieta, E.; et al. Gut microbiota, bacterial translocation, and interactions with diet: Pathophysiological links between major depressive disorder and non-communicable medical comorbidities. Psychother. Psychosom. 2017, 86, 31-46. [CrossRef] [PubMed]

100. Gopalakrishnan, V.; Spencer, C.N.; Nezi, L.; Reuben, A.; Andrews, M.C.; Karpinets, T.V.; Prieto, P.A.; Vicente, D.; Hoffman, K.; Wei, S.C.; et al. Gut microbiome modulates response to Anti-PD-1 immunotherapy in melanoma patients. Science 2018, 359, 97-103. [CrossRef] [PubMed] 
101. Kim, S.M.; DeFazio, J.R.; Hyoju, S.K.; Sangani, K.; Keskey, R.; Krezalek, M.A.; Khodarev, N.N.; Sangwan, N.; Christley, S.; Harris, K.G.; et al. Fecal microbiota transplant rescues mice from human pathogen mediated sepsis by restoring systemic immunity. Nat. Commun. 2020, 11, 2354. [CrossRef]

102. D'Amato, A.; Di Cesare Mannelli, L.; Lucarini, E.; Man, A.L.; Le Gall, G.; Branca, J.J.V.; Ghelardini, C.; Amedei, A.; Bertelli, E.; Regoli, M.; et al. Faecal microbiota transplant from aged donor mice affects spatial learning and memory via modulating hippocampal synaptic plasticity- and neurotransmission-related proteins in young recipients. Microbiome 2020, 8, 140. [CrossRef]

103. Lleal, M.; Sarrabayrouse, G.; Willamil, J.; Santiago, A.; Pozuelo, M.; Manichanh, C. A Single faecal microbiota transplantation modulates the microbiome and improves clinical manifestations in a rat model of colitis. EBioMedicine 2019, 48, 630. [CrossRef]

104. Moayyedi, P.; Surette, M.G.; Kim, P.T.; Libertucci, J.; Wolfe, M.; Onischi, C.; Armstrong, D.; Marshall, J.K.; Kassam, Z.; Reinisch, W.; et al. Fecal microbiota transplantation induces remission in patients with active ulcerative colitis in a randomized controlled trial. Gastroenterology 2015, 149, 102-109.e6. [CrossRef] [PubMed]

105. Costello, S.P.; Hughes, P.A.; Waters, O.; Bryant, R.V.; Vincent, A.D.; Blatchford, P.; Katsikeros, R.; Makanyanga, J.; Campaniello, M.A.; Mavrangelos, C.; et al. Effect of fecal microbiota transplantation on 8-week remission in patients with ulcerative colitis: A randomized clinical trial. JAMA 2019, 321, 156-164. [CrossRef] [PubMed]

106. Narula, N.; Kassam, Z.; Yuan, Y.; Colombel, J.F.; Ponsioen, C.; Reinisch, W.; Moayyedi, P. Systematic review and meta-analysis: Fecal microbiota transplantation for treatment of active ulcerative colitis. Inflamm. Bowel Dis. 2017, 23, 1702-1709. [CrossRef] [PubMed] 